\title{
신경병성통증의 병태생리
}

권 오 현

을지대학교 의과대학 의정부을지대학교병원 신경과

\section{Pathophysiology of neuropathic pain}

\author{
Ohyun Kwon, MD \\ Department of Neurology, Uijeongbu Eulji Medical Center, Eulji University School of Medicine, Uijeongbu, Korea
}

\begin{abstract}
Background: Neuropathic pain is notoriously difficult to manage properly, not only because of its varied nature and the absence of objective diagnostic tools but also because of extensive reciprocal neuronal interactive pathogenic mechanism from the molecular level to patient's own psychophysical characteristics. This paper briefly reviews the pathophysiology of neuropathic pain to the level of clinicians' interest and its potential in clinical practice Current Concepts: Recent research progress now allows us to obtain a bird view of neuropathic pain pathophysiology: peripheral and central sensitization. For peripheral sensitization, a local inflammatory milieu of the injured nerve primarily drives sequential phenotypic changes, which are critical and shared by both neuropathic and inflammatory pain. Central sensitization is led either by the hyperexcitability of the second-order afferent neuron itself or loss of physiological inhibitory control of the transmission of pain signal to the higher nervous system. Peripheral and central sensitization work synergistically but can also introduce neuropathic pain alone.

Discussion and Conclusion: The cause of neuropathic pain is diverse, and understanding of its pathophysiology is still insufficient to realize a mechanism-based approach to clinical phenotypes or therapeutic applications. In dealing with chronic neuropathic pain, it is highly desirable to assess key aspects of a patient's pain based on a plausible mechanism and select the best management method accordingly.
\end{abstract}

Key Words: Inflammation; Nerve fibers; Neuropathic pain; Pathophysiology

\section{서론}

신경병성통증은 체성감각 신경계의 병터나 질환에 의해 발생하는 통증으로 규정한다[1]. 체성감각은 표면감각과 고 유감각을 포함하지만, 정상 생리적인 경우에서나 병적인 경

Received: June 13, 2021 Accepted: June 23, 2021

\section{Corresponding author: Ohyun Kwon E-mail: koh1407@eulji.ac.kr}

(C) Korean Medical Association

This is an Open Access article distributed under the terms of the Creative Commons Attribution Non-Commercial License (http://creativecommons. org/licenses/by-nc/3.0) which permits unrestricted non-commercial use, distribution, and reproduction in any medium, provided the original work is properly cited.
우에서나 통증과 연관된 체성감각 신경계는 기계적수용, 온 도수용, 통각의 표면감각을 관장하는 신경계로 국한된다. 신 경병성통증은 원인 병터가 신경말단이 있는 피부에서부터, 신경, 신경얼기, 신경뿌리의 말초신경, 척수, 뇌줄기, 시상, 주변계(limbic system), 섬고랑 등의 대뇌피질까지 전체 체 성감각 신경계에 걸쳐 가능하므로, 신경병성통증의 발생과 지속에 관여하는 신경계 부위나 기전 역시 전체 체성감각 신 경계와 이를 조율하는 신경계 전반에 걸쳐 있다. 게다가 환 자마다 전신 어디에서나 특정 신체 부위에, 다른 원인 질환 을 가지고 있고, 통증 특성이 개인마다 두드러진 차이가 있 을 정도로 다양함을 고려할 때 신경병성통증은 매우 이질 적이고 다양한 과정의 보편적인 결과라 할 수 있다. 그러므 
로 신경병성통증에 관한 연구는 임상연구나 기초연구 상관 없이 뇌신경과학의 가장 큰 주제 중의 하나이며, 그 연구대 상은 피부에 있는 통증감각 신경섬유 손상 부위에서 시작하 여, 대뇌피질에 이르기까지 신경계의 모든 해부학적 영역에 걸쳐 분포한다. 이처럼 분야가 방대하다는 것은 특정한 기 전이 신경병성통증 전체를 설명할 수 없고, 다양한 생물학 적 기제가 상호 영향을 주고받으며 나타나는 역동적인 과정 임을 시사한다.

통각통증과 신경병성통증은 두 개의 완전히 분리되어 있 는, 정상 생리적 과정과 비정상 병적 과정으로 대립한다고 오해할 수 있지만, 실제로는 두 현상은 일련의 생리반응이라 고도 할 수 있다. 조직 손상을 일으키는 자극으로 통각통증 이 생겼다 하더라도 자극으로 조직이 손상되면 필연적으로 따르는 조직의 재생과 그를 위한 일련의 염증활동은 체성감 각 신경계의 활성화를 유도하여 통각자극에 민감도를 높이 고(통각과민), 닿는 수준의 촉각의 무해자극도 통증으로 느 끼게 한다(무해자극통증). 이를 염증통증이라 하며, 염증조 직의 통증에 대한 활성화는 말초신경병에 의한 신경병성통 증의 시작과 같은 신경펩타이드, 사이토카인(cytokine), 효 소 등 물질을 공유하고, 활동의존성 형성력을 포함한 다양한 공통 기제에 의한다. 그리고 엄밀하게는 염증조직 안의 표피 속신경섬유의 통증신경섬유도 함께 조직 손상 자체나 손상 에 따른 이차적 염증에 의해 침범되기에 통각통증과 동시에 미세신경병성통증도 함께 발생한다고 할 수 있다[2]. 게다가 만성관절염 등에 의해 염증통증이 지속적으로 유지되면, 통 증의 양상이 변하는데(통증의 강화 및 난치성), 이 과정 역 시 신경병성통증의 기제가 그대로 작동하기 때문에, 만성통 증 관리의 원칙으로 소염진통제 사용 등 통각통증의 관리뿐 만 아니라 신경병성통증(혹은 그에 해당하는 기전에 의한 통 증) 관리 역시 중요한 이유이기도 하다[2,3]. 이러한 사실에 기반하여 통증을 통각통증, 염증통증, 신경병성통증, 기능 이상통증(염증이나 신경 손상은 없지만, 일차성홍색팔다리 통증[primary erythromelalgia]이나 섬유근육통과 같이 통 각의 말초성 그리고 중추성 증폭에 의한 통증)으로 구분하 기도 한다[4].

최근 수십 년간의 신경병성통증과 관련된 동물실험과 임
상연구로 신경병성통증 병태생리에 대한 이해는 매우 넓고 깊어졌다. 이에 맞춰 임상현장에서는 표현형에 따른 병태생 리의 주 기전을 파악하고 약제 선택의 논리적 길잡이로 고 려할 수 있다[5-8]. 그러나 아직도 상반된 결과로 논란이 남아 있는 해부학적, 병태생리적 현상 소견들이 많고, 관찰 된 해부학적, 생리적 형질 변화에 연관된 분자생물학적 기 전은 여전히 규명하지 못한 부분이 산재해 있다. 게다가 연 구로 밝혀진 신경병성통증의 병태생리가 신경병성통증 환 자의 관리 개선으로 번역되는 성과는 기대만큼 빠르지 못 해서 신경병성통증은 의학적 관심과 개입에도 불구하고 만 족스러운 결과를 얻지 못하고 여전히 난치성인 것이 사실 이다.

신경병성통증은 통증 전달 경로의 해부학적, 기능적 변화 에 의해 두 개의 통증 관리의 축인 상행성 경로의 비정상적 인 혹은 병적인 활성화 내지 촉진, 그리고 하행성통각조절 경로의 기제 혹은 작용 변화로 두 축의 생리적인 균형이 깨 지고, 결과적으로 통증 전달 체계가 병적 과흥분성 상태를 지속하는 데에 기인한다[9]. 부적응의 형성력에 의한 병적 변화가 있는 체성감각 신경계 상행성 경로의 해부학적 부 위에 따라 신경병성통증의 기전을 구분하며, 통각을 전달 하는 등뿌리신경절이나 삼차신경절에 세포체를 둔 일차감 각신경의 변화인 말초성 민감화와, 척수 뒤뿔의 이차감각 신경부터 대뇌피질에 이르기까지의 중추신경계 변화인 중 추성 민감화로 구분한다. 하행성조절경로의 기능적 변화는 척수 뒤뿔의 이차감각신경인 투사 신경 섬유의 활성으로 반 영되기에 중추성 민감화의 한 기전으로 포함해서 설명하는 경우가 많다.

\section{통증의 전달 경로}

신경회로의 관점에서 볼 때, 통증감각은 몸통과 팔다리의 경우 등뿌리신경절에 세포체를 둔 일차감각신경이 척수 뒤 뿔로, 안면이나 머리 앞쪽의 표피, 그리고 두개강 내 구조 물의 경우에는 삼차신경절에 세포체를 둔 일차감각신경(삼 차신경)이 척수삼차신경핵으로 가서 이차감각신경과 만난다 
A

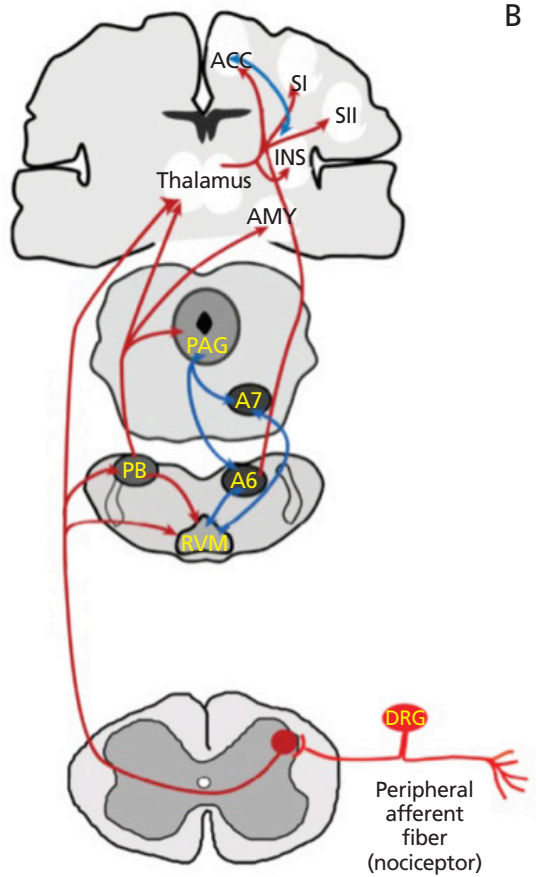

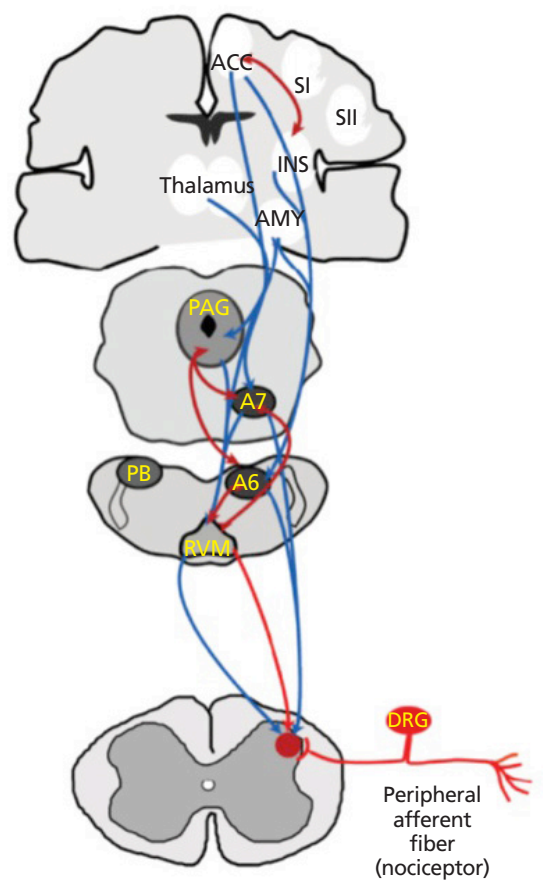

Figure 1. The perception and endogenous modulation of pain. Nociceptive inputs enter the central nervous system at the spinal dorsal horn where primary afferent terminals synapse with second-order projection neurons. (A) The ascending tracts of lateral spinothalamic tract and spinoparabrachial tract are represented. the 2-headed arrows indicate bilateral communications. (B) Descending projections are shown, and the 2-headed arrows indicate bilateral communications. The descending projections from the RVM to the spinal cord include both inhibition and facilitation depending upon their neurotransmitter and receptor. The A6 and A7 are noradrenergic nuclei and exert inhibitory modulation on the spinal projection neuron at the dorsal horn. ACC, anterior cingulate cortex; AMY, amygdala; DRG, dorsal root ganglion; INS, insular cortex; PAG, periaqueductal gray; $\mathrm{PB}$, parabrachial nuclei; RVM, rostroventromedial medulla; $\mathrm{SI}$, primary somatosensory cortex; SII, secondary somatosensory cortex. Adapted from Ossipov MH. Scientifica (Cairo) 2012;2012:561761, according to the Creative Commons Attribution License [10].

(Figure 1) [10]. 통각은 얇은말이집신경섬유인 $\mathrm{A} \delta$ 신경섬유 와 민말이집신경섬유인 $\mathrm{C}$ 신경섬유를 통해 전달된다. $\mathrm{A} \delta$ 신 경섬유는 급성이면서 잘 국소화된 빠른 첫 통증을, $\mathrm{C}$ 신경섬 유는 다소 불분명하게 국소화된 느린 두 번째 통증을 전달 한다[11]. C신경섬유는 다양한 종류의 자극에 대해 반응하 는데 한 신경섬유에 여러 통각수용체가 발현한다. 대표적인 통각수용체로는 열에 민감한 transient receptor potential cation channel subfamily V1(TRPV1), 찬 것에 민감한 TRPM8, 산성 환경에 반응하는 acid-sensing ion channel, 여러 화학물질에 반응하는 TRPA1 등이 있다. 조직의 손상 을 초래할 수 있는 유해한 온도, 기계적, 화학적 자극은 이 와 같이 다양한 높은 역치의 통각수용체의 활성화로 일차감 각신경의 활동전위를 만든다. 펩타이드성 $\mathrm{C}$ 신경섬유와 높 은 역치의 $\mathrm{A} \delta$ 신경섬유는 척수 겉판(superficial laminae) 인 Rexed lamina I에 있는 이차감각신경인 neurokinin-1

수용체 발현 투사신경세포나 outer lamina II (IIo)에 있는 사이신경세포에 신호를 전달한다. Lamina I (marginal) 은 강한 수준의 자극이 전달되어, 통각 특이적(nociceptive specific)이라 지칭 하기도 한다. 비펩타이드성 C신경섬유 는 등쪽 inner lamina II (IIid)의 사이 신경세포를 만난다. 높은 역치의 $\mathrm{A} \delta$ 신 경섬유는 lamina I과 outer lamina II 뿐만 아니라 깊은 뒤뿔인 lamina $\mathrm{V}$ 로 도 신호를 전달한다. 낮은 역치의 기 계수용체 $\mathrm{A} \delta$ 신경섬유와 $\mathrm{C}$ 신경섬유는 낮은 역치의 기계수용체 $\mathrm{A} \beta$ 신경섬유 와 함께, 배쪽 inner lamina II (IIid)의 protein kinase $\mathrm{C}$ gamma 발현 사이신 경세포로 향한다. $\mathrm{A} \beta$ 신경섬유의 중추 말단은 lamina III부터 V까지 분포한다. Lamina $\mathrm{V}$ 을 중심으로 분포하는 이차구 심성섬유인 wide-dynamic-range 신 경세포는 $A \beta$ 신경섬유에 오는 무해자극 뿐만 아니라, $\mathrm{A} \delta, \mathrm{C}$ 신경섬유에서 오는 자극까지 표피나 장기의 모든 구심성 자극을 수용하고, 사이 신경세포와 밀접하게 연결되어 흥분성 혹은 억제성 영향을 통합하여 보다 위신경계로 정보를 전달한다[12].

이차통각구심성신경의 중추 경로는 크게 둘로 구분하 여, 첫째는 시상으로 가는 가쪽척수시상로 혹은 삼차시 상로의 외측 경로, 그리고 둘째는 숨뇌(medulla)에 위치 한 꼬리쪽배가쪽숨뇌(caudal ventrolateral medulla), 등 쪽그물핵(dorsal reticular nucleus, 혹은 subnucleus reticularis dorsalis), 뇌다리의 팔곁핵, 중간뇌의 수도관 주위회색(periaqueductal gray), 뇌줄기 전반에 걸친 그 물체(reticular formation) 등 뇌줄기 안의 신경핵으로 향 하는 척수숨뇌로(spinomedullary tract), 척수뇌다리로 (spinopontine tract), 척수중간뇌로(spinomesencephalic tract)를 거쳐 위쪽 중추신경계로 통증감각을 전달한다[12]. 특히, 뇌줄기에서 편도, 시상하부, 주변계로 통각 신호를 전 
달하는 중심 연결인 팔곁핵으로 올라가는 척수의 상행로를 특정하여 척수팔곁로(spinoparabrachial tract) 혹은 삼차팔 곁로(trigeminoparabrachial tract)로 따로 부르기도 한다. 척수시상로와 삼차시상로의 목적지는 체성감각 시상인 배쪽 뒤가쪽핵, 배쪽뒤안쪽핵뿐만 아니라 안쪽 그리고 배안쪽시 상(medial and ventromedial thalamus)으로도 투사하여, 체성감각 시상에서 시작하는 삼차구심성신경은 통증의 양 상, 위치나 강도 등을 분별하는 일차, 이차감각피질(SI, SII) 로, 그리고 안쪽, 배안쪽 시상에서 시작하는 삼차감각신경 은 뒤섬이랑(posterior insular gyrus), 앞띠고랑(anterior cingulate gyrus, ACG)의 주변앞뇌(limbic forebrain)로 향 해서 통증의 정서적 혹은 감정적 측면을 코딩한다. 팔곁핵 등 뇌줄기에서 시작하는 구심성신경은 위 뇌줄기, 시상하부, 시상의 배쪽뒤핵과 섬유판속핵(intralaminar nucleus), 정 중선핵(midline nucleus), 편도, 바닥앞뇌(basal forebrain) 로 가서, 통증의 정서적 반응, 자율신경 반응, 회피 학습, 그 리고 하행성통각조절경로의 활성화 등에 관여한다[13]. 그 러므로 특정 대뇌피질에 국한된 통증센터라 할 만한 뇌부위 는 존재하지 않으며, 통각 신호는 흔히 'pain matrix'라 불리 는 여러 개의 대뇌와 사이뇌 부위를 활성시키는데, 일차 및 이차 체성감각이랑, 섬이랑, ACG, 이마앞엽피질(prefrontal cortex), 편도, 시상하부가 포함된다. 일부에서는 국소적인 마루엽 손상 이후 중추성 혹은 말초성 신경병성통증의 소실 을 보고한 증례들을 근거로 하여, SI을 포함하는 마루시상축 (parietothalamic axis)이 신경병성통증의 국소적 발생지이 며, 다른 통증과 관련한 부위는 마루시상축의 활성에 이은 connectome을 따라 활동하게 되는 물결효과(ripple effects) 로, 통각에 의해 활성화될 수 있지만, 통각에만 특이적이진 않는 인지 과정을 반영한다고 보고 있다[14].

하행성통각조절경로는 수도관주위회색, 청색반점 (locus coeruleus), ACG, 편도, 시상하부를 거쳐 숨뇌, 특 히 입쪽배안쪽 숨뇌(rostral ventromedial medulla)를 통 해 척수로 신호를 전달한다. 관여하는 신경전달물질은 norepinephrine (noradrenaline), 5-hydroxytryptamine (5-HT, serotonin), dopamine, 내인 아편유사제들이다. 특 히 norepinephrine은 대표적인 억제 경로의 신경전달물질
로 척수의 $\alpha 2$ 수용체를 통해 뒤뿔의 통증 투사 신경섬유를 억제한다. 5-HT는 수용체의 종류에 따라 억제성 또는 촉진 성일 수 있으며, 촉진성 조절에는 대표적으로 $5-\mathrm{HT}_{3}$ 수용체 가, 억제성으로는 $5-\mathrm{HT}_{7}$ 수용체가 알려져 있다[15].

\section{신경병성통증의 병태생리}

\section{1. 말초성 민감화}

1) 국소염증, 그리고 통각수용체와 이온통로의 활성화

신체 국소 조직의 손상은 해당 조직에 있는 신경이나 신 경가지를 함께 침범한다. 조직이나 신경 자체의 손상에 따 른 염증은 이온통로의 발현과 민감화를 유도한다(Table 1) [16].

$\mathrm{A} \delta$ 신경섬유와 $\mathrm{C}$ 신경섬유 말단에는 신경종이 생기고 그 부위에서 역행성 활성화를 통해 신경성 염증이 유도된다. Calcitonin gene related peptide (CGRP)나 substance P (SP) 등의 신경펩타이드가 분비되고, 이는 혈관 통과성의 증 가로 혈관 확장과 혈관바깥유출을 포함하여 이미 손상된 부 위의 염증을 더욱 조장한다. 손상된 조직에서 그리고, 주변 염증세포에서 염증매개물질의 분비가 증가하는 데 대표적 염증매개물질로 히스타민, bradykinin, 5-HT (serotonin), adenosine triphosphate, prostaglandin E2, leukotriene $\mathrm{B} 4$, 수소이온, 신경성장인자, interleukin-1 $(\mathrm{IL}-1 \beta)$, IL-6, tumor necrosis factor- $\alpha(\mathrm{TNF}-\alpha)$, leukemia inhibitory factor 등이 있고 이를 염증죽(inflammatory soup)이라 할 수 있다[17]. 손상된 일차구심성신경섬유는 통 각수용체와 이온통로의 유전자 전사를 촉진, 나트륨통로와 칼슘통로의 발현 증가하고, 또한 통각수용체는 인산화 과정 으로 민감화되어 흥분성이 증가된다[12,18].

TRPV1 등의 TRP 수용체, acid-sensing ion channel, adenosine triphosphate 민감성 P2X3 퓨린성 수용체, Piezo 1/2, calcium-permeable AMPA 수용체를 포함하 는 통각수용기, 그리고 신경의 활동전위 생성에 필요한 전 압작동이온통로(voltage-gated ion channel)인 Nav1.3, Nav1.7, 그리고 Nav1.8의 나트륨통로 그리고 N-type 칼 
Table 1. Proposed model for the relationship between neuropathic pain mechanisms and clinical symptoms and signs, and possible targets for therapeutic interventionse

\begin{tabular}{|c|c|c|}
\hline Mechanisms & Symptoms & Targets/compounds \\
\hline \multicolumn{3}{|l|}{ Peripheral nociceptor hyperexcitability } \\
\hline Ectopic impulse generation, oscillations in DRG & SP, shooting & $\begin{array}{l}\text { Sodium channels blocker: lidocaine, CBZ, OCB, } \\
\text { lamotrigine, TCA }\end{array}$ \\
\hline \multicolumn{3}{|l|}{ Peripheral nociceptor sensitization } \\
\hline Inflammation within tissue & SP, ongoing & \\
\hline $\begin{array}{l}\text { Increased release/expression of proinflammatory } \\
\text { cytokines/chemokines and their receptors from } \\
\text { injured tissue and nerve or by neurogenic } \\
\text { inflammation }\end{array}$ & & $\begin{array}{l}\text { Cytokine antagonist: TNF- } \alpha \text { antagonists } \\
\text { COX blocker: NSAIDs }\end{array}$ \\
\hline \multicolumn{3}{|l|}{ Reduced activation threshold to: } \\
\hline Heat & Heat allodynia & TRPV-1 receptor antagonists: capsaicin \\
\hline Cold & Cold allodynia & TRPV-8 receptor antagonists: menthol \\
\hline Mechanical stimuli & Static mechanical allodynia & ASIC receptor antagonists \\
\hline Noradrenaline & SMP & $\begin{array}{l}\alpha \text { receptor antagonist: phenolamine, sympathetic } \\
\text { block, TCA }\end{array}$ \\
\hline Histamine & - & H1-receptor antagonists: TCA \\
\hline \multicolumn{3}{|l|}{ Dorsal root ganglion hyperexcitability } \\
\hline Activation of $\mathrm{Na}^{+}$and $\mathrm{HCN}$ channels & - & \\
\hline Infiltration of immune cells, neurtrophils, T-cell & - & \\
\hline Infiltration of glial cells, satellite glial cells & - & Neuron-neuron communication via gap junction \\
\hline \multicolumn{3}{|l|}{ Central nervous system hyperexcitability } \\
\hline Central sensitization on spinal level & $\begin{array}{l}\text { SP, ongoing } \\
\text { Dynamic and punctate mechanical allodynia }\end{array}$ & \\
\hline \multicolumn{3}{|l|}{$\begin{array}{l}\text { Ongoing C-input inducing increased synaptic } \\
\text { transmission }\end{array}$} \\
\hline Amplification of C-fiber input & - & \\
\hline \multirow[t]{8}{*}{ Gating of $A \beta$ and $A \delta$ fiber input } & - & Presynaptic: \\
\hline & & $\mu$-receptors agonists: opioids \\
\hline & & $\begin{array}{l}\text { Calcium channel blocker ( } \alpha 2-\delta \text { ligands): GBP, PGB, } \\
\text { ziconotide }\end{array}$ \\
\hline & & Postsynaptic: \\
\hline & & $\begin{array}{l}\text { NMDA-receptor antagonists: ketamine, } \\
\text { dextromethorphan }\end{array}$ \\
\hline & & NK1-receptor antagonists \\
\hline & & Selective sodium channel blocker: CBZ \\
\hline & & MAPK mediators \\
\hline \multicolumn{3}{|l|}{$\begin{array}{l}\text { Loss of intraspinal inhibitory interneurons } \\
\text { (functional, degenerative) }\end{array}$} \\
\hline GABA-ergic, glycine-ergic, opioidergic & - & $\begin{array}{l}\mathrm{GABA}_{B} \text { agonists: baclofen } \\
\mu \text {-receptor agonist: opioids }\end{array}$ \\
\hline \multicolumn{3}{|l|}{ Neuro-glial interaction } \\
\hline Microglia, astrocyte & - & MAPK mediator, BDNF, TNF- $\alpha$, other cytokines \\
\hline \multicolumn{3}{|l|}{ Changes in supraspinal descending modulation } \\
\hline Inhibitory control (NA, 5-HT) & - & $\begin{array}{l}\text { a2-receptor agonists: clonidine } \\
\text { NA/5-HT-reuptake blocker:TCA, venlafaxine, } \\
\text { duloxetine }\end{array}$ \\
\hline Facilitatory (5-HT), enhanced & & - \\
\hline Reorganization of "pain matrix" & & \\
\hline
\end{tabular}

Adapted from Baron R. Handb Exp Pharmacol 2009;(194):3-30, with permission from Springer Nature [16].

DRG, dorsal root ganglion; SP, spontaneous pain; CBZ, carbamazepine; OCB, oxcarbazepine; TCA, tricyclic antidepressants; TNF- $\alpha$, tumor necrotic factor- $\alpha$; COX, cyclooxygenase; NSAIDs, non-steroidal anti-inflammatory drugs; TRPV1, transient receptor potential cation channel subfamily V member 1; TRPM8, transient receptor potential cation channel subfamily M member 8; ASIC, acid-sensing ion channel; TCA, tricyclic antidepressant; SMP, sympathetically maintained pain; NMDA, N-methyl-D-aspartate; NK1, neurokinin-1; GBP, gabapentin; PGB, pregabalin; CBZ, carbamazepine; MAPK, mitogen-activated protein kinase; TNF- $\alpha$, tumor necrosis factor- $\alpha$; GABA, g-aminobutyric acid; BDNF, brain-derived neurotrophic factor; NA, noradrenaline; 5-HT, 5-hydroxytryptamine (serotonin). 
슘통로의 과발현과 민감화로, 정상 상태에서는 통각수용체 를 활성화할 수 없는 낮은 강도의 무해자극에도 일차통각신 경섬유의 활동전위를 유도하여 일차성 무해자극통증과 기 존의 통증 강도 자극에는 더 크게 반응하는 일차성 통각과 민의 증상으로 나타난다. 함께 이온통로의 병적인 활성화 로 자극이 없는 상태에서도 자발통증이 유발된다. 유전자 발 현의 변화로 낮은 역치의 기계자극의 무해자극을 감지하는 $\mathrm{A} \beta$ 신경섬유도 원래 $\mathrm{C}$ 신경섬유와 $\mathrm{A} \delta$ 신경섬유에서 분비되는 $\mathrm{SP}, \mathrm{CGRP}$ 를 발현하여, 무해자극통증 발생에 기여할 수 있 다[12,18].

\section{2) 등뿌리신경절의 변화}

이러한 민감화 과정은 신경말단에만 국한하지 않고, 신경 의 축삭, 그리고 신경세포체가 있는 등뿌리신경절에서도 나 타난다. 이온통로의 딴곳 확산(heterotopic proliferation)은 축삭의 활동전위 전도를 더욱 촉진하며, 자극 역치를 낮추 어 이소성 방전을 초래한다. 등뿌리신경절에서도 통각을 증 폭하는데, 이소성 방전뿐만 아니라, T임파구, 대식세포, 중 성구 등의 염증세포와 satellite glial cells가 침윤하여 연접 한 서로 다른 분류인 $\mathrm{A} \delta$ 신경섬유, $\mathrm{C}$ 신경섬유, $\mathrm{A} \beta$ 신경섬유 간에 gap junction을 통한 전기시냅스전달에 의한 활동전 위 전파 발생을 유도할 수 있다. 또한 등뿌리신경절에는 교 감신경섬유가 주변에서 가지 쳐서 들어오는데, 신경세포의 $\alpha$-adrenoreceptor의 발현, 교감신경매개 혈관 수축에 의한 산소와 영양의 부족의 기전을 통해 통증이 지속하는데 기여 한다.

\section{2. 중추성 민감화}

중추성 민감화는 사용의존성 시냅스 가소성의 한 형태로, 척수에서 일어나는 long-term potentiation이라 비유할 수 있다[4].

\section{1) 척수 내 이차구심성신경섬유의 민감화}

척수 내 신경의 항진된 흥분성은 낮은 역치의 기계민감 성 $\mathrm{A} \beta$ 와 $\mathrm{A} \delta$ 구심성섬유가 이차통각수용신경들을 활성화시 킬 수 있게 한다. 일차통각구심신경의 중심 축삭 말단은 척 수 뒤뿔을 거쳐 척수의 회질에서 이차통각구심신경이나 사 이신경세포와 만난다. 글루타민, 글리신의 흥분성 아미노
산, brain-derived neurotrophic factor, 그리고 CGRP, $\mathrm{SP}$, neurokinin $\mathrm{A}$ 의 신경펩타이드를 분비하고 이온통로 와 함께 작용하여 이차통각수용신경에서 활동전위가 발생 한다. 신경 손상은 글루타민 수용체를 활성화하고, 글루타민 운반체(transporter)를 줄여 시냅스 내 글루타민 농도를 높 인다. 신경 손상의 경우와 마찬가지로 통각신호가 지속적이 고 반복적으로 발생하여 척수로 전달되면, N-methyl-Daspartate (NMDA) 수용체와 $\alpha$-amino-3-hydroxy $-5-$ methyl-4-isoxazolepropionic acid (AMPA) 수용체의 인 산화를 통해 칼슘의 세포 내 유입을 비롯하여 신호 전달을 촉진하는 시냅스 후 변화를 일으킨다. NMDA 수용체는 신 경병성통증의 유도, 통각과민, 그리고 신경병성통증의 지속 에 관여하며, 신경구조의 변화 및 흥분독성을 통해 신경병 성통증의 지속에 핵심적인 역할을 한다. 그리고 말초 영역 에서 신경 손상 이후 염증세포/면역세포가 손상 부위로 침 윤하는 것과 유사한 척수 내 반응으로 손상된 일차감각신경 의 척수 쪽 신경말단에서 colony stimulating factor 1 을 분 비하여, 주위로 미세아교세포가 침윤하고, 별아교세포와 함 께 구조적, 기능적 변화를 거쳐 $\mathrm{IL}-1 \beta, \mathrm{IL}-6$ 와 $\mathrm{TNF}-\alpha$ 등 염증매개물질의 농도가 높아지고 중추신경계의 민감화에 기 여한다.

정상적인 환경에서는 척수 내 $\gamma$ aminobutyric acid $(\mathrm{GABA})$ 또는 글리신 분비 사이신경세포가 겉층에서 일 차통증감각을 지속적으로 억제하는 상태를 유지한다. 정 상적인 상태에서는 일차구심성 탈분극(primary afferent depolarization)의 증가에 대응하여 사이신경세포의 GABA 에 의한 시냅스전 억제가 더 강화되지만, 강한 통증감각 이 지속적으로 척수 뒤뿔의 중심 신경말단으로 쏟아져 전 달되는 조직의 손상이나 염증, 혹은 말초신경손상의 경우 에는 GABA 분비 사이신경세포의 세포사를 유도하고, 활 동하는 사이신경세포들도 NMDA, non-NMDA 수용체가 활성화되어 $\mathrm{GABA}$ 분비가 줄고, $\mathrm{TNF}-\alpha$, brain-derived neurotrophic factor 등에 의한 억제성 GABA의 역할 감소 를 유도한다. 심지어 억제성 사이신경세포가 더 이상 억제 성 기재가 아니고 역으로 흥분성 기재로 작동하게 된다[19]. 일차감각신경으로 역행성 활동전위로 되먹이는 dorsal root 
reflex도 통각신경세포를 지속적으로 흥분된 상태를 유지하 는 데 기여한다. 또 다른 척수 내 중요 억제방법인 아편유사 제 수용체를 통한 억제는 $\mathrm{NMDA}$ 수용체의 활성화로 인해 진 통 효과가 떨어지고, 또한 $\mu$-opioid receptor 발현을 억제하 는 cholecystokinin이 증가하여 아편유사제 투여에 따른 진 통효과가 기대에 미치지 못하게 된다.

$\mathrm{C}$ 신경섬유와 $\mathrm{A} \delta$ 신경섬유인 일차통각신경섬유가 손상되 면, 정상적으로는 척수의 Rexed laminae III-IV에서 이차감 각신경세포와 만나는 $\mathrm{A} \beta$ 신경섬유가 겉층인 Rexed lamina II로 신경가지를 내어, 통각투사신경을 활성화시켜, 임상적 으로는 무해한 자극을 통증으로 인식하게 하는 무해감각통 증과 연관된다.

\section{2) 하행성통증조절경로의 변화}

신경 손상 후에 하행성통증조절경로의 noradrenaline의 지속 억제가 줄고, 5-HT에 의한 통증조절이 촉진성으로 기 능함이 알려져 있다[2]. 하행성통증조절경로의 통증에 미치 는 영향을 검사하는 방법으로 conditional pain modulation $(\mathrm{CPM})$ 이라는 정신신체적 검사 방식이 있는데, 같은 강도의 통증 자극이라도 미리 선행하는 조건화 자극을 할 경우, 시 험 통증 자극의 강도를 덜하게 느끼는지 여부로 확인할 수 있다[20]. 신경병성통증 환자의 일부에서는 하행성통증조절 경로가 통각지향성 혹은 촉진성 통증조절을 보인다. $\mathrm{CPM}$ 이 촉진성 프로파일인 신경병성통증은 촉진을 줄여줄 수 있는 gabapentinoid와 같은 약제를, $\mathrm{CPM}$ 이 억제성 프로파일인 경우엔 억제성 활동을 더 강화하는 세로토닌노아드레날린재 흡수억제제(serotonin-noradrenaline reuptake inhibitors) 인 duloceptol 혹은 venlafaxine를 시도해 볼 수 있다[21].

3) 중추성 신경병성통증

척수, 뇌줄기, 그리고 시상 등의 대뇌구조물의 손상이나 기능이상으로 유발되는 중추성 신경병성통증은 기본적으로 시상을 포함한 척수시상로나 삼차시상로의 부분 손상이 필 수적이다[22]. 일부 유지된 척수시상로의 신경 과흥분성으 로 신경병성통증이 발생하며, 척수시상로 자체의 과흥분성 혹은 해당 경로의 탈억제가 주된 기전이다. 척수손상의 경 우 손상된 척수시상로에 미세아교세포에 의한 활성화 그리 고 시상 병터의 경우 가쪽시상(lateral thalamus)의 GABA
성 신경세포의 손상으로 온전하게 남아 있는 통증 전달 시상 경로의 탈억제, 그리고 통증 연관 대뇌피질로의 비정상적인 신호 전달이 대표적 실험 근거이다. 가벼운 접촉, 진동, 그리 고 고유감각(proprioception)을 전달하는 lemniscal system 의 손상은 중추성 신경병성통증의 발생에 그리 관여하지 않 는 것으로 알려져 있다[23,24].

\section{신경병성통증의 유전적 연구}

신경병성통증은 신경병, 척수손상, 뇌졸중 등 다양한 질 환에서 흔히 동반되는 합병증이지만, 신경병성통증을 동반 하는 대표적인 경우인 당뇨병다발신경병 등에서도 신경병 성통증의 유무, 강도는 환자마다 크게 차이 날 수 있다. 이 처럼 환자의 신경병성통증 발생을 조장하는 변수로 우울증, 불안증 등의 정신신경계질환 그리고 환경적 요인 등이 있지 만, 통증의 감수성이나 통증의 지속에 미치는 유전적 영향은 분명하다[7]. 드물지만, 단일 유전자 돌연변이로 신경병성통 증이 발생하는 경우는 가족성홍색팔다리통증의 Nav1.7의 $\mathrm{SCN} 9 \mathrm{~A}$ 경우를 대표로 하여, 신경병성통증을 동반하는 다양 한 유전성신경병들이 그 예다[25]. 당뇨병다발신경병, 신경 뿌리통증, 인간면역결핍바이러스 연관 신경병, 대상포진 후 신경통, 수술 후 통증등의 흔한 질환에서 신경병성통증 발생 에 취약한 유전자형을 찾기 위한 연구에서 여러 유전적 변이 가 보고되었지만, 이제껏 연구들에서는 전체적으로 유전적 영향은 크지 않은 수준이었다. 나트륨통로의 de novo gainof-function missense 변이가 특발성통증소섬유신경병이 나 통증성당뇨병신경병 환자의 $10 \%$ 수준에서 확인되었다 [18]. 통증성당뇨병신경병을 대상으로 한 전체유전체 상관분 석연구 연구에서 교차비 0.6 의 보호적 변이와 교차비 1.6 수 준의 취약성 변이 등을 확인하였으나, 전체적으로 narrowsense heritability는 11-14\% 수준이라 보고하였다[2527]. 취약성유전자로 catechol-O-methyltransferase, major histocompatibility complex 유전자, 아편유사체수용 체 $\mu 1$, GTP cyclohydrolase $1, \mathrm{IL}-6, \mathrm{TNF}-\alpha$ 등이 신경병 성통증과의 연관성이 보고된 바 있다[18]. 
신경병성통증은 원인 질환도 다양할 뿐만 아니라, 임상 표 현형이나 치료약제의 적용의 기제 기반 접근을 실현하기엔 병태생리의 이해는 아직도 충분하지 않은 것이 사실이다. 그 렇지만 벤치의 기초연구에 얻은 지식이나 개념을 신경병성 통증 환자의 임상적 관리의 길잡이로 활용하고 그 결과를 병 태생리적으로 해석하는데 적용하는 것이 난치성 신경병성통 증 환자를 보는 의사에게 요구되는 바람직한 자세임은 분명 하다[18]. 진료실에서 환자가 호소하는 신경병성통증의 성 상을 구체적으로 파악하고, 이를 통해 그 환자 고유의 신 경병성통증의 병태생리를 이해하고, 그에 맞춘 약제 선택으 로 보다 나은 신경병성통증의 관리 성과를 기대할 수 있다 $[2,7,16,18,28]$.

\section{찾아보기말: 염증; 신경섬유; 신경병성통증; 병태생리}

\section{ORCID}

Ohyun Kwon, https://orcid.org/0000-0001-9806-814X

\section{Conflict of Interest}

No potential conflict of interest relevant to this article was reported.

\section{References}

1.Treede RD, Jensen TS, Campbell JN, Cruccu G, Dostrovsky JO, Griffin JW, Hansson P, Hughes R, Nurmikko T, Serra J. Neuropathic pain: redefinition and a grading system for clinical and research purposes. Neurology 2008;70:1630-1635.

2.Cohen SP, Mao J. Neuropathic pain: mechanisms and their clinical implications. BMJ 2014;348:f7656.

3. Kuner R, Flor H. Structural plasticity and reorganisation in chronic pain. Nat Rev Neurosci 2017;18:20-30.

4.Costigan M, Scholz J, Woolf CJ. Neuropathic pain: a maladaptive response of the nervous system to damage. Annu Rev Neurosci 2009;32:1-32.

5. Gilron I, Baron R, Jensen T. Neuropathic pain: principles of diagnosis and treatment. Mayo Clin Proc 2015;90:532-545.
6. Rice ASC, Finnerup NB, Kemp HI, Currie GL, Baron R. Sensory profiling in animal models of neuropathic pain: a call for back-translation. Pain 2018;159:819-824.

7.von Hehn CA, Baron R, Woolf CJ. Deconstructing the neuropathic pain phenotype to reveal neural mechanisms. Neuron 2012;73:638-652.

8.Scholz J, Mannion RJ, Hord DE, Griffin RS, Rawal B, Zheng H, Scoffings D, Phillips A, Guo J, Laing RJ, Abdi S, Decosterd I, Woolf CJ. A novel tool for the assessment of pain: validation in low back pain. PLoS Med 2009;6:e1000047.

9. Colloca L, Ludman T, Bouhassira D, Baron R, Dickenson AH, Yarnitsky D, Freeman R, Truini A, Attal N, Finnerup NB, Eccleston C, Kalso E, Bennett DL, Dworkin RH, Raja SN. Neuropathic pain. Nat Rev Dis Primers 2017;3:17002.

10.Ossipov MH. The perception and endogenous modulation of pain. Scientifica (Cairo) 2012;2012:561761.

11.Basbaum AI, Bautista DM, Scherrer G, Julius D. Cellular and molecular mechanisms of pain. Cell 2009;139:267-284

12.Peirs C, Seal RP. Neural circuits for pain: recent advances and current views. Science 2016;354:578-584.

13.Benarroch EE. Parabrachial nuclear complex: multiple functions and potential clinical implications. Neurology 2016; 86:676-683.

14.Canavero S, Bonicalzi V. Pain myths and the genesis of central pain. Pain Med 2015;16:240-248.

15.Bannister K, Dickenson AH. The plasticity of descending controls in pain: translational probing. J Physiol 2017;595:41594166.

16.Baron R. Neuropathic pain: a clinical perspective. Handb Exp Pharmacol 2009;(194):3-30.

17.Vranken JH. Mechanisms and treatment of neuropathic pain. Cent Nerv Syst Agents Med Chem 2009;9:71-78.

18.Finnerup NB, Kuner R, Jensen TS. Neuropathic pain: from mechanisms to treatment. Physiol Rev 2021;101:259-301.

19.Chen J, Han JS, Zhao ZQ, Wei F, Hsieh JC, Bao L, Chen CAN, Dai Y, Fan BF, Gu JG, Hao SL, Hu SJ, Ji YH, Li YJ, Li YQ, Lin Q, Liu XG, Liu YQ, Lu Y, Luo F, Ma C, Qiu YH, Rao ZR, Shi L, Shyu BC, Song XJ, Tang JS, Tao YX, Wan Y, Wang JS, Wang KW, Wang Y, Xu GY, Xu TL, You HJ, Yu LC, Yu SY, Zhang DY, Zhang DR, Zhang JM, Zhang X, Zhang YQ, Zhuo M. Pain. In: Pfaff DW, editors. Neuroscience in the 21st century: from basic to clinical. New York: Springer; 2013. p. 965-1023.

20. Yarnitsky D. Role of endogenous pain modulation in chronic pain mechanisms and treatment. Pain 2015;156 Suppl 1:S24S31.

21.Yarnitsky D, Granot M, Nahman-Averbuch H, Khamaisi M, Granovsky Y. Conditioned pain modulation predicts duloxetine efficacy in painful diabetic neuropathy. Pain 2012 153:1193-1198.

22. Watson JC, Sandroni P. Central neuropathic pain syndromes. 
Mayo Clin Proc 2016;91:372-385.

23.Vestergaard K, Nielsen J, Andersen G, Ingeman-Nielsen M, Arendt-Nielsen L, Jensen TS. Sensory abnormalities in consecutive, unselected patients with central post-stroke pain. Pain 1995;61:177-186.

24.Boivie J, Leijon G, Johansson I. Central post-stroke pain--a study of the mechanisms through analyses of the sensory abnormalities. Pain 1989;37:173-185.

25.Zorina-Lichtenwalter K, Parisien M, Diatchenko L. Genetic studies of human neuropathic pain conditions: a review. Pain 2018;159:583-594.

26.Meng W, Deshmukh HA, Donnelly LA; Wellcome Trust Case Control Consortium 2 (WTCCC2); Surrogate markers for Micro- and Macro-vascular hard endpoints for Innovative diabetes Tools (SUMMIT) study group, Torrance N, Colhoun HM, Palmer CN, Smith BH. A Genome-wide association study provides evidence of sex-specific involvement of Chr1p35.1 (ZSCAN20-TLR12P) and Chr8p23.1 (HMGB1P46) with diabetic neuropathic pain. EBioMedicine 2015;2:1386-1393.

27.Meng W, Deshmukh HA, van Zuydam NR, Liu Y, Donnelly LA, Zhou K; Wellcome Trust Case Control Consortium 2 (WTCCC2); Surrogate Markers for Micro- and MacroVascular Hard Endpoints for Innovative Diabetes Tools (SUMMIT) Study Group, Morris AD, Colhoun HM, Palmer $\mathrm{CN}$, Smith $\mathrm{BH}$. A genome-wide association study suggests an association of Chr8p21.3 (GFRA2) with diabetic neuropathic pain. Eur J Pain 2015;19:392-399.
28.Baron R, Binder A, Wasner G. Neuropathic pain: diagnosis, pathophysiological mechanisms, and treatment. Lancet Neurol 2010;9:807-819.

\section{Peer Reviewers' Commentary}

이 논문은 신경병성통증에 관여하는 신경해부 구조와 생리, 그 리고 지금까지 밝혀진 신경병성통증의 발생기전을 말초성과 중 추성 민감화 기제를 중심으로 소개하고 있다. 신경병성통증의 치 료가 만족스럽지 못한 이유 중 하나는 기전에 근거한 치료가 이 루어지지 않고 있기 때문이다. 신경병성통증은 체성감각신경계 의 병터나 질환에 의해 발생하며 말초신경부터 대뇌에 이르는 신 경계 경로 전반에서 신경병성통증이 야기될 수 있으므로 신경병 성통증의 병태생리를 숙지하는 것이 환자를 통증으로부터 해방 시킬 수 있는 토대가 된다. 통증 전달 경로의 신경해부학적 개요 와 더불어 국소염증, 통각수용체 및 이온통로의 활성화, 등뿌리 신경절의 변화로 생기는 말초성 민감화와 척수내 이차구심신경 섬유의 민감화, 하행통증조절경로의 변화로 생기는 중추성 민감 화까지 잘 정리하였다. 이 논문은 신경병성통증의 병태생리 이해 를 통해 환자 진료에 많은 도움을 줄 수 있을 것으로 판단된다.

[정리: 편집위원회] 